\title{
From positivism to generative mechanisms: Raymond Boudon's path-breaking research programme
}

\section{Mohamed Cherkaoui}

Emeritus Senior Research Fellow. Centre National de la Recherche Scientifique (CNRS) cherkaoui@msh-paris.fr

\begin{abstract}
This paper briefly compares two research traditions: empiricism and generative mechanisms. Moreover, it briefly recalls the arguments of empiricist epistemology and its philosophical justification, whose paradigmatic expression is positivism. The paper then examines the criticisms that have been addressed against this trend and sets out the principles of the generative mechanisms strategy in sociology by focusing on several studies by Boudon which are the most representative of this methodological orientation.
\end{abstract}

Keywords: empiricism; epistemology; causal explanation; rationality.

Resumen. Del positivismo a los mecanismos generativos: el programa de investigación pionero de Raymond Boudon

Este artículo compara brevemente dos tradiciones de investigación: la del empirismo y la de los mecanismos generativos. Además, recuerda también brevemente los argumentos del empirismo epistemológico y su justificación filosófica, cuya expresión paradigmática es el positivismo. El artículo examina, pues, las críticas que se han dirigido contra esta tradición y expone los principios de la estrategia de los mecanismos generativos en sociología limitándose a las investigaciones de Boudon, que son las más representativas de esta orientación metodológica.

Palabras clave: empirismo; epistemología; explicación causal; racionalidad. 


\begin{tabular}{|c|c|}
\hline \multicolumn{2}{|c|}{ Summary } \\
\hline 1. Introduction & 4. On phenomenalism and its critique \\
\hline $\begin{array}{l}\text { 2. Why has empiricist epistemology } \\
\text { been dominant? }\end{array}$ & $\begin{array}{l}\text { 5. From generative mechanisms } \\
\text { to a general theory of rationality }\end{array}$ \\
\hline 3. Boudon's new research strategy & Bibliographic references \\
\hline
\end{tabular}

\section{Introduction}

The idea that a phenomenon is explained by constructing basic mechanisms that generate it is certainly not new. It can be traced back to Greek philosophers. However, it is only very recently that it has become a research strategy. By abandoning the classifications of natural history and by seeking to understand the causes of the invariance of certain characteristics of life or those viral or microbial causes responsible for particular diseases, biology was one of the early first sciences to implement the principles of the new methodology.

Breaking with the empiricist approach inherited from an interpretation of the natural philosophy of Newton, physics has been involved in the same way. Taxonomy remained nevertheless dominant but not exclusive in linguistics until recently. It is helpful to recall that formalist theoreticians, Chomsky (1964) for example, have played a critical role in the emergence of the generative approach. In sociology, systematisation and codification of generative mechanisms methodology took place later. The first attempt by Simon (1952, 1955) hardly had any influence on the sociological community. It is only with the seminal works of Boudon as well as Fararo (1969a, 1969b, 1989) that this research strategy began to be viewed as distinctive and its fruitfulness recognised.

In this contribution, I shall briefly compare the two research traditions. Moreover, without claiming to identify all the reasons that explain the almost exclusive dominance of empiricist methodology, I shall briefly recall the arguments of its epistemological and philosophical justification, whose strongest expression is positivism. I shall then examine the criticisms that have been directed at it and set out the principles of the strategy of generating models in sociology limiting myself to Boudon's research studies that are the most representative of this methodological orientation.

\section{Why has empiricist epistemology been dominant?}

According to the positivist programme, which had and still has a great influence on sociology, social phenomena are explained when correlations are identified by empirical analyses of functional relationships between variables. Why has such a methodological approach been dominant in social sciences? There are, I think, four reasons, namely the social demand for "cameral sciences" following Schumpeter's phrase - that is, action-oriented sciences, the growing power of statistical techniques and computer technology, the institutional and social prestige of quantitative sociology, and finally, the intellectual comfort 
that this approach provides. It is possible to identify the epistemological principles of such a mode of explaining social phenomena by studying the philosophical foundations upon which most current empirical research studies are based. However, one can reach the same objective by analysing the formal discourse of the sociological method, which has been historically the expression and justification of this strategy.

Empirical sociology today is the true forerunner of the nineteenth-century emerging sociology. It has been the result of a triple tradition, namely Comte's positivism, moral statistics and epistemological empiricism dominant in all sciences at the beginning of this century. There are surely some divergences between the protagonists of these three movements, but they actually share the same conception of this new science of society they aspired to create. If, for example, Quételet and moral statisticians on the one hand, and Comte and the positivist school on the other hand, did not agree on the use of probability theory in social sciences, they shared the same epistemological principles of empirical scientism that dominated science since the victory of Newtonian physics, or - to be more accurate - since the philosophical interpretation that most philosophers have given of this science. There are four principles:

I) According to the first principle, science must reject metaphysics and separate the empirical data from any ontology. Human beings and social phenomena are therefore "naturalised" in order to be subjected to scientific investigation, namely to observations, indirect experiments, and historical method according to Auguste Comte, and to measure according to Quételet and moral statisticians.

II) According to the second principle, the ultimate goal of scientific study is to demonstrate that phenomena comply with laws. Ideally, any explanation is supposed to be reduced to a mathematical function. Here, I would like to quote one of the most eloquent positivist texts borrowed from the Course of Positive Philosophy ${ }^{1}$ :

In the final, the positive state, the mind has given over the vain search after absolute notions, the origin and destination of the universe, and the coituses of phenomena, and applies itself to the study of their laws, that is, their invariable relations of succession and resemblance. Reasoning and observation, duly combined, are the means of this knowledge. What is now understood when we speak of an explanation of facts is simply the establishment of a connection between single phenomena and some general facts, the number of which continually diminishes with the progress of science.

This extract from the first lesson of the Course of Positive Philosophy meets the famous introduction of Sur l'homme et le développement de ses facultés (On Man and the Development of his Faculties) where Quételet explains his conception of naturalistic laws and macro-social regularities.

1. In this paper all translations are mine. 
III) For the third principle, the rejection of any metaphysics banishes any scientific research into the realm of causes or generating mechanisms of phenomena. This is a leitmotif in the Course of Positive Philosophy.

We shall admit, in physics, as a fundamental principle of the true theory of the institution of the assumptions, that any scientific hypothesis to be really tested (French text says "judgeable") should exclusively focus on the laws of phenomena and never on their modes of production.

Pierre Duhem (1906: 26), who influenced not only the Vienna Circle, but also all the twentieth-century positivists, is the heir of Comte's thought when he defines physical theory as follows: "a physical theory is not an explanation. It is a system of mathematical propositions, deduced from a small number of principles, which aims to represent as simply as completely, and as accurately as possible a set of experimental laws."

Later, Paul Samuelson (1964) says nothing else when he replies to Machlup (1964): "Scientists never 'explain' any behavior by theory or by any other hook. Every description that is superseded by a "deeper explanation" turns out upon careful examination to have been replaced by still another description."

For the father of positivism, Newton was right to limit his search to stating laws and not trying to explain, while Descartes was wrong in pretending to go further by offering accountability of laws by the swirls hypothesis. Who was really right, Descartes or Newton? For those who seek to predict, compute and act, specifically for Comte and the positivists, the English scientist approach is the right one. For those who want to understand the mechanism of movement, for example, Newton's theory is not satisfactory, and Descartes has at least the merit of having tried to decipher the puzzle in the second book of his Principles of Philosophy even if his explanation is laughable.

Quételet does not say anything else: he denies being a theorist, he rejects any system, and he voluntarily limits his search to the facts and to the study of their patterns.

In the eyes of positivist and social statisticians, as in the eyes of all those who were frightened by the rise of the "dangerous classes" and their "social harms," it is absurd to try to explain and understand phenomena with theories based on the rationality assumption as the Enlightenment philosophers wanted. The rational man of the eighteenth century belongs to the elite that are able to calculate probabilities, while the average man does not have this distinctive feature. During the Enlightenment, moral sciences endeavoured to reveal the rational foundations of action and belief. For them, society was also governed by laws insofar as it is an aggregation of rational individuals. In the nineteenth century on the other hand, social sciences sought to highlight social patterns and abandon the microscopic level of individual action. For them, society was governed by laws despite the irrationality of its members. It is well known that the theme of the irrationality of crowds and of the individual is commonplace in the nineteenth-century sociological literature. 
More than that: even the use of assumptions, which are regarded merely as artifacts, is strictly prohibited. Auguste Comte distinguishes two kinds of assumptions. The first one, which is legitimate and authorised, concerns the analysis of phenomena in order to discover their laws. The second one, which is prohibited, is related to the nature, the cause or the mode of production of phenomena. The conclusion of the basic theory of assumptions developed in the twenty-eighth lesson of the Course of Positive Philosophy is that "any scientific hypothesis to be really subject to judgment should exclusively focus on the laws of phenomena and never on their modes of production". Quite obviously, the founder of positivism shares the empiricist interpretation of Newton's natural philosophy, which makes the English physicist a positivist avant la lettre. In fact, for the empiricists, the famous aphorism "hypotheses non fingo" is a profession of faith according to which Newton would have declared unlawful the search for explanations by hypothesis. Actually, the famous adage is taken from a passage of the Mathematical Principles of Natural Philosophy where Newton recognised that he was unable to find a hypothesis that could explain the properties of gravity. He therefore knew that gravitation requires an explanation, that is to say, something that goes beyond the law.

IV) According to the fourth principle, action is the ultimate goal of sciences, including social sciences. On this point, there is a consensus between Saint Simon, social reformers, Comte and Quételet who are the heirs of the French Idéologues. However, the action depends on the forecast that rests on the knowledge of the laws governing phenomena.

At the turn of the nineteenth century, some biologists and physicists broke with the traditional research programme corresponding to the macroscopic approach of Newtonian astronomy and physics. They developed a new paradigm consistent with new theories (e.g. viral, genetic, particle), and the problems posed by the micro-physical phenomena.

Claude Bernard is undoubtedly one of the first scientists to have understood the limits of empiricism and positivism, which were dominant in the late nineteenth century. In his Introduction to Experimental Medicine and in his Principles of Experimental Medicine, he opposed the empiricist doctor of the Hippocratic School to which the positivists belonged, and the experimentalist physician he represents himself. While the first observes and describes; the second leads experimentations, that is to say experiences brought about according to theoretical assumptions. If the empiricist relies on the statistical relationship between treatments and diseases, he is however unable to answer the question of why the administration of such pharmacopoeia has an effect on this particular disease.

"Empiricism stops science and dulls the mind, when one rests on it," Bernard (1947: 75) says. "The empiricist is satisfied when he manages to heal. The experimental doctor wants to go further and to penetrate with experimentation by explaining the vital mechanisms. The real goal of the researcher is to know and understand the generative mechanisms of the disease or, in the words of Claude Bernard (1947: 137), "the mechanism producing disease." 
One perceives a similar attitude in physics at the beginning of the twentieth century that Emile Meyerson (1921: 62) admirably summed up:

Just have a look at the collection published by the Council (the Brussels Congress of Physics in 1911) that reflects the communications that have been presented and the discussions they provoked, to find that the sole purpose of all this work was the search for a true physical theory, an assumption on the mode of production (so odious to Auguste Comte and inadmissible, indeed, according to his conception of science).

The strength of positivism is largely due to the belief according to which it is a philosophy that expresses, founds and justifies the new science. In its various forms, positivism was a philosophy of the nineteenth-century scholar. But it sometimes continues to play the same role today. As a research strategy seeking to explain nomologically and providing psychological satisfaction with a minimum intellectual investment, positivism is ineradicable because it is a lifeline to which clings the researcher who is often unable to speculate on the generative mechanisms of phenomena. At times, it happens we are positivist, and at times we reject positivism.

In the nineteenth century, few people understood the negative consequences of these epistemological principles and attempted to replace them with others. In his Rules of the sociological method, Durkheim (1895) remained a prisoner of the positivist dogma. However, in his research studies, the author of Suicide and The Elementary Forms of Religious Life tried to break with certain principles of positivist philosophy by demonstrating the inadequacy of nomological activity and the need to explain the laws themselves. It has been shown (Boudon, 1990, 1998b; Cherkaoui, 1997, 1998, 2008) that a sketch of a new strategy based on the search of the modes of production of social phenomena can be found in the work of the French sociologist that he neither developed nor systematised. It should be added that no one has been able to achieve this programme, even the most anti-positivist sociologist of his generation, namely Gabriel Tarde.

Let us now turn to contemporary sociology. Many research studies belong partly to the empiricist tradition. The methodology of multivariate analyses of large-scale quantitative data is based on the principles of the positivist model. This is the case of the work of Stouffer, Lazarsfeld and the Columbia school although some of them, including Lazarsfeld and Merton, expressed dissatisfaction here and there with the nomological explanation and tried to formulate hypotheses whose kinship with generative models is obvious. However, such assumptions remain ad hoc and ex post.

\section{Boudon's new research strategy}

In the 1960 s, a new research programme in sociology appeared simultaneously and independently in Boudon's and Fararo's works, to mention only the most 
representative work of this new trend which broke with the positivist model and its nomological explanation. The mode of explanation of this new strategy was to highlight the mechanisms that generate regularities of phenomena in a way identical to biology, physics or linguistics.

The merit of Boudon is to have clarified the principles of such a strategy, and to have tested them in such a vital domain as the sociology of mobility and social inequalities, proving their fruitfulness, and expanding their fields of application. He clearly saw their links with the paradigm of methodological individualism and the general theory of rationality, both of which he devoted the rest of his intellectual life to (Boudon 2009, 2010). It is noticeable that, at the same time, and obviously independently, Harré (1970) proposed a realistic philosophy advocating the same perspective.

The idea of explaining by social mechanisms runs through the work of Tocqueville, Durkheim, Simmel, Weber, or Merton (Cherkaoui, 2005), but in none of them was it recognised, developed and applied to such wide areas as did Boudon, Fararo, Simon (1952, 1955, 1968) or later Schelling (1978). Moreover, in the early 1970s, Boudon's approach was so unusual that even such acute minds as Hauser (1974) had trouble in understanding it. His critical review of Boudon's Opportunity and Social Inequality was evidence of a deep and symptomatic misunderstanding: there is indeed a dichotomy between the positivist empiricism that dominated research on mobility in particular and sociology in general, and the new research programme proposed by Boudon.

A quick examination of the development and directions displayed in Boudon's work offer a division of his oeuvre into three stages. The first period is dominated by contributions to the construction of statistical and mathematical models in the tradition of his friend Lazarsfeld (Boudon, 1967). A second period covers the late 1960s and 1970s up to the publication of La place du désordre in 1984 (translated in Theories of social change, 1986). It is characterised by the first version of the theory of rationality applied to social mobility, inequality and change. The third period has been marked by his efforts to generalise his theory and extend it to the most various topics and issues, such as ideological, scientific, and religious beliefs (Boudon, 1999, 2009, 2011).

It would not be difficult to point out the change of direction in Boudon's sociological work that first became evident at the end of the 1960s. He moved away from the studies whose main inspiration was the Lazarsfeldian tradition to a novel form of sociology whose primary concern was the construction of a new strategy based on the discovery of generative mechanisms; an approach systematised in Boudon (1973) L'inégalité des chances (translated in Education, Opportunity and Social Inequality, 1974), but actually visible in two articles written in the late sixties and published in the European journal Quality and Quantity, with the significant titles "Essai sur la mobilité sociale en Utopie" (Essay on social mobility in utopia) and "Éléments pour une théorie formelle de la mobilité sociale" (Elements for a formal theory of social mobility). In fact, this innovation was not an ex nihilo creation. Boudon had been for some time seeking a new methodology that could allow sociology to get out of the 
rut in which it was stuck. In fact, in the article "La statistique psychologique de Tarde" which appeared in 1964, the premises of the new methodologi$\mathrm{cal}$ orientation were revealed. Another article published in the same year by Boudon (1964b) with an even more suggestive title "Les mécanismes sociaux des abandons de poursuite" (Social mechanisms of prosecution dropouts) provides a still better example of how the new methodology could be applied to a specific area.

Boudon's methodology rests on five principles of analysis that will inform his later work. Firstly, he refuses to consider the correlation analysis or any standard statistical technique as an explanatory mode of phenomena. Secondly, he regards as impossible or at least highly difficult to draw any reliable conclusions from a direct reading of data tables since any table is only a provisional stage that is unable to express correctly the social process that generates it. Thirdly, for him sociological phenomenon is the result of complex social processes which require the use of longitudinal analyses. Fourthly, macrophenomena are the results of behaviours of partially autonomous social actors and their interaction structure (independence or interdependence). Finally, it seems necessary to build psychological and cognitive models to understand these behaviours.

Let us examine some significant aspects of Boudon's interpretation of Tarde's criminal studies. Tarde, he notes, is less interested in the explanation of crime but focuses on that of mechanisms of repression. For him, the statistical series to be explained are the joint product of an act, crime, and the judiciary institution. This judiciary may "class" without result, suppress or discharge. The statistical regularities are largely the product of judicial treatment. However, these macro-patterns are the result of interactions between actors with specific social roles and that mutually influence each other. To understand the functioning of judicial institutions, it is necessary to distinguish two sets of actors. The first, the magistrates, is characterised by interaction or reciprocal influences. The defendants and juries, who form the second set of actors, do not interact with each other. This distinction helps to explain the differences between some longitudinal data series: on the one hand, the proportion of prisoners who appeal the decision of criminal courts remain stable over time, while the proportion of appeals by the prosecution decreases during the same period. In the first case, the actors' independence explains the stability, while the interdependence between judges who monitor each other and anticipate their respective decisions accounts for the decline.

\section{On phenomenalism and its critique}

The positivist explains by establishing laws that he seeks to derive from other more general laws and so on. In its simplest form, the lawful relation is an expression, often mathematical, between at least two phenomena such as distance and time in Galileo-Descartes's law of falling bodies, or suicide and marital status in Durkheim's (1897) theory of integration. These relations are 
empirical generalisations or laws with limited validity. The positivist explains the law of falling bodies by deriving it from Newton's laws of gravitation and motion. But sometimes he will face problems that cannot be solved in the context of his epistemology. To solve them, he will therefore be condemned to violate some of his principles. Let us limit ourselves to the following sociological examples.

Suppose we study the relationship between two variables X and Y. Assume that a correlation between the two variables is deduced from the analysis of empirical data from a cross-sectional survey. The empiricist will, however, face many problems if he wants to deduce certain consequences from this empirical fact.

Firstly, he cannot be sure that the relationship is a real one. Admittedly, he uses the basic rules of multivariate analysis to test whether or not the relationship is a true one by taking into account control variables. Actually, he is unsure that all relevant control variables have been taken into consideration in his analyses. Moreover, the assumption of a closing system of relations between variables is only a convenient fiction - the assumption allows us to suppose that exogenous factors (i.e. not controlled) are not simultaneously correlated with independent and dependent variables, but it does not tell us anything about the relevance of our choice of endogenous and exogenous variables. The ceteris paribus rule is itself no longer of any help.

Secondly, we should consider the case where data from a new survey show no correlation between the variables under study. If so, would we be allowed to conclude that these new data falsify this correlation? Certainly not! We therefore are in an undecidable situation.

Thirdly, the dependence between variables sometimes says nothing on the meaning of their relationship. Does the growth of education precede industrialisation? Or does the reverse hold? Should we rather suppose a retroaction effect between them? Here again, the empirical analysis does not allow us to decide.

Fourthly, if any modelling of the relationship between two phenomena (i.e. any identification of nomological invariance) is built on the basis of $\mathrm{N}$ observations, it is therefore possible to construct empirically not one but a very large number of mathematical "laws". Can we empirically make sure that a specific law is valid? Certainly not! All those laws are empirically valid. Actually, we often apply the principle of simplicity to choose a model among all those which are theoretically possible. However, this principle is frequently violated for theoretical reasons. Suppose an empiricist wishes to study the relationship between the size of the family and suicide rate on the basis of data provided by Durkheim in Suicide. The first order linear regression model between the dependent variable $(S)$ and the independent variable $(F)$ provides an excellent fit which gives a value of $\mathrm{R}^{2}=0.915$.

$$
\mathrm{S}=1609.6-3.64 \mathrm{~F}
$$

The linear regression model with a negative slope expresses the Durkheimian proposition according to which when the density of the family increases, 
the likelihood of suicide decreases. Such a result would satisfy the most demanding empiricist. A more complex model is, however, preferred because it is deduced from the theory of integration, according to which when integration increases, the suicide rate decreases and then increases. This theoretically based proposition is expressed by a parabolic model. From the same empirical data, the estimated parameters are

$$
S=7515-34,051 \mathrm{~F}+0,039 \mathrm{~F}^{2}
$$

In this case, the value of $\mathrm{R}^{2}=0.97$ is greater than that given by the first order regression. I am not saying that the parabolic model is better than the firstorder model on the basis of the value of $\mathrm{R}^{2}$. If the parabolic model "explains" a greater percentage of the variance than the linear one does, it is because it contains an additional parameter. Choosing a model rests on the sole theory and not on the results of analyses of empirical data.

The simplicity principle cannot be therefore a selection criterion. If we base our choice on numerous examples borrowed from the history of science, we will be inclined to believe that frequently the more complex model is preferable to the simplest one. A classic example is the astronomical theory that describes the motion of planets around the sun. Kepler's ellipsoidal model is more complex than Copernicus's circular model.

To explain the correlation and make it understandable, the empiricist is usually forced to construct hypotheses on the mechanisms that generate empirical regularity. In doing so, he is no more an empiricist. But this is a post hoc strategy of generative mechanisms. In general, what he calls interpretative assumptions at the end of his research are mostly ad hoc and cannot be generalised.

Let us borrow from Boudon (1973) a suggestive example of an ad hoc mechanism. Different studies have demonstrated that social mobility changes according to various factors such as the increase in school enrolment, economic development, the nature of stratification such as the presence of legally established strata in the past as states in Europe. Lipset and Zetterberg (1956) noted that, contrary to what was thought, the mobility rate was only very slightly different in Europe and in the United States. They tried to improve the theory by introducing the hypothesis of the existence of a mechanism that would explain why the aspiration to climb the social ladder is small. According them, this aspiration is especially low when social barriers are less visible: where social distinctions are imperceptible, the income inequality is low and the standard of living is high, and the individual does not seek to improve his/her social status. If the United States has a mobility rate similar to that in Europe, this is due to factors whose conflicting effects nullify each other: the United States has no legally defined social hierarchy as in Europe; it has a less visible stratification than in the old continent. The combination of greater ease and less aspiration to climb the social ladder therefore makes intelligible the relative uniformity of mobility rates between societies whose systems of stratification are different. We have here a rudimentary but good example of the use of a post hoc mechanism. 
As Boudon (1973) emphasises, the explanation being ad hoc, the only consequence that can be drawn is the proposition itself it seeks to explain. Boudon does not claim that what he calls factor analysis can be of no help despite its limitations and weaknesses. He disqualifies it as a scientific research strategy insofar as its objective is to explain and to understand phenomena. The aim of research in the empiricist approach is to find a relationship between the "explicandum" and the "explanans" as in statistical analyses. In the most favourable interpretation, this research strategy sometimes assumes the existence of a black box between the two variables that is either of no interest or difficult to observe, to decompose and to describe, as Bunge notes (1967). We will see later how the theory of rationality tries to avoid the existence of the black box in explaining phenomena.

Boudon goes further in his critique of factor analysis. He observes that whatever the degree of generality of the observed relations between variables, and assuming they are not spurious, they remain unintelligible and therefore offer no explanation insofar as we do not identify the generative mechanisms of phenomena and their co-occurrences, that is to say, essentially the reasons for actors' behaviours. There are reasons that convert the power of the actor to perform actions. Actions are therefore only observable effects of reasons. Reasons are not causes in Hume's meaning; they are yet intrinsic traits of actions. They are logically related to actions. Of course, the positivist can always protest against the fact that reasons are empirically inaccessible and that they remind him of metaphysical entities. Actually, this argument is unconvincing since, like physicists and biologists, we accept that unobserved entities may be requested to explain, providing that their traces are empirically controlled.

In fact, identifying dependency relationships between phenomena is a particular and feeble case of nomological activity. Suppose that the sociologist points out invariant relations between phenomena, and that he can therefore subsume under laws the phenomena he is studying. According to Hempel's (1965) deductive-nomological theory, a phenomenon is explained when one can deduce it from a general law and its particular antecedents. However, there are several general laws that do not explain the relationship between the phenomena they bind and do not make them comprehensible. One can recall many regularities in physics for instance. Consider the examples borrowed from Hempel (1965). Kepler's laws describe well the path of the planets around the sun, but do not explain it. The ideal gas law PV = a $T$ that links the pressure $P$, volume $V$ and temperature $T$, specifies how each factor varies depending on the other two, but tells us nothing about the mechanisms that account for these relationships. The explanation was possible later with the kinetic molecular theory. The law is indubitably derived from the molecular theory; nevertheless, the explanation does not reside in this deduction. It lies in the fact that the macro-phenomena are caused by microscopic phenomena according to theoretically built mechanisms. We will see later that what is valid in physics and biology is valid in sociology or social sciences. 
It is clear that, according to the deductive-nomological model, to explain a phenomenon is solely to subsume it under laws and to deduce these laws from more general laws, exactly as required by Auguste Comte. It is true that this model does not justify the explanation by black boxes, but it certainly contributes to moving the scientist away from the search for generative mechanisms anathematised by Auguste Comte.

\section{From generative mechanisms to a general theory of rationality}

We are not always able to produce explanations without black boxes. When we use collective concepts or notions that we are unable to deduce from the structures of individual interactions, or when we ignore their mode of production, we can be assured that black boxes exist in the chain of reasons we give to make intelligible the phenomenon under study. How can we explain the behaviour of individuals in a crowd? How is it that "an assembly of harmless bourgeois can turn into a fearsome monster", according to Durkheim's (1897) famous phrase? For LeBon (1895), the individual undergoes a radical transformation in a crowd that makes the emergence of primitive and irrational elements possible. The person loses control of himself and behaves like an animal. The basic mechanism by which LeBon elucidates this behaviour is the "suggestion", that is, accepted orders given to that person. The person is literally hypnotised. Why does the "primitive" believe in magic? For Lévy-Bruhl (1922), their magical beliefs are explained by the fact that they have the "primitive mentality" different from the "civilised mentality". Why do students from different social origins formulate different educational demands although they are of the same age, educational level and scholastic attainment? Why do working class students prefer lower-level education than upper-middle class students? To explain this correlation, let us suppose that the sociologist argues that it is because children are socialised differently or that they do not have the same "habitus". Why do French social scientists produce more books than scientific articles compared to their American colleagues (Boudon, 1986; Cherkaoui, 2011 for a systematisation and a generalisation of the market theory based on empirical data)? A possible answer is that France has a "cultural specificity". "Suggestion", "primitive mentality", "socialisation", "habitus", and "cultural specificity" are black boxes insofar as we are unable to specify the mechanism that meets these vague notions.

How can we explain without black boxes, according to Boudon (1998a)? He distinguishes two types of explanation with mechanisms. The first one "gives the impression that the explanation is final" in the sense that our search ends. Being satisfied at least temporarily by the responses we give, we do not ask more questions. For the second one, the explanation does not seem to have exhausted all the questions that are likely to be asked. In some cases indeed, there are theories that use mechanisms but do not belong to the methodological individualist paradigm, as in the example of the explanation of the demand for education by socialisation (or some macro-structural theories). 
Let us examine the example of crowd behaviour. Coleman (1990) shows that the structure of the game of this phenomenon is not comparable to that of the prisoner's dilemma since, in crowds, there is communication between the actors. We cannot therefore assert that there is a dominant strategy, which would be running to the fire exit in the event of a fire in a theatre. He notes that the concepts of suggestion, contagion, and social facilitation can be interpreted in terms of "transfer of power." In some situations indeed, the individual divests himself of the power or control he normally has of his own actions and transfers it to others. This interpretation has the advantage of making the action the result of an intentional act and allows us to ask the question why and in what circumstances the rational actor operates such a transfer. In addition, such a perspective can make the difference between groups; for example, between those who have potentially extremist behaviour and the others.

The behaviour of an assembly or a crowd in a closed space does not necessarily result in panic; it depends on the initial action of the actors who have not transferred their power to others: if it is quiet, the subsequent actions will also be so. Suppose that player A knows that the other players act independently of his behaviour. In his interest, he should try to quickly leave the room because he knows that his action has no effect on the actions of others. If, however, A knows that his action has an effect on others, he knows at the same time that fleeing can result in a traffic jam whose costs will be very high for him and for others. Escaping would be beneficial for him only if he is next to a door. It is more advantageous for him than for the others to leave the room in order. If the actions of others depend entirely on his action, it is in his interest to dictate orders so that the evacuation takes place peacefully. The situation is different if he assumes that each of the other group members does not act independently of him but has transferred to him and to others partial control. A can estimate that it is his interest either:

1) to run to the exit regardless of what others do,

2) to try to go out calmly regardless of what others do,

3) to try to go out quietly firstly, and secondly matching his action to that of others. All this depends on the degree of power that others have transferred to him, the probability that they will run towards the exit, and the benefits actor A can gain from each situation. We find ourselves in a situation characterised by the interdependence between actors, where an actor cannot define a rational strategy if he ignores the strategy of others.

Coleman's explanation is satisfactory and temporarily ultimate for the following reasons:

1) It answers all our why-questions,

2) It takes into account all possible scenarios (fleeing, go out in order, etc.). Unlike the theory that seeks to explain the consequences of only one behaviour, such as bottling, 
3) It uses the same assumptions to account for all behaviours, contrary to the assumption according to which the actor is sometimes rational and sometimes irrational,

4) It generates the macro-phenomena from micro-social behaviours, that is to say behaviours of individuals that have the same properties but that are involved in different interaction structures.

The fact that the ultimate causes are related to individual decisions implies that the explanation by a social mechanism has been made in terms of the methodological individualist paradigm.

As a model that abstractly reproduces the phenomenon to be explained, the generative mechanism provides an interpretation in terms of individual behaviours. It considers the social actor as the sociological atom who is generally individual. It excludes structures and therefore any attempt to reify them, as Weber (1922b) taught us. The sociological explanation is intelligible because it refers to intentions, reasons or causes and consequences of the individual agent actions. But if the paradigm of methodological individualism is necessarily associated with the strategy of generative mechanisms, it is however not always easy to apply. In fact, according to the epistemological status of a particular research domain, it is sometimes difficult or even temporarily impossible to give an explanation at the individual level (see Cherkaoui, 2007).

Two options are open. In the first one, the most radical, the researcher refuses to take into consideration in any explanation macro-social phenomena or normative concepts that are not explained and reduced to their individual behaviours. In the second one, which is more flexible, one provisionally accepts these macro-phenomena. As elements of our explanation, norms, rules or institutions for example are provisionally accepted in this second option and rejected in the first one, even though both versions agree that these variables are an intended or unintended consequence of individual interactions or the result of the crystallisation of long historical processes that the researcher is not yet able to explain but should make intelligible later (Cherkaoui, 2007).

One can therefore understand why Boudon (1998a) draws attention to the fact that the methodological individualist paradigm offers no immunity against the presence of black boxes in a sociological explanation. It is a necessary but not sufficient condition. To be protected against any risk of infection, one should couple this paradigm with the assumption of rationality. If we want our explanation to be entirely satisfactory, we should express the ultimate causes in fully understandable individual actions, namely based on reasons. In other words, those social actors are not victim to any hidden and unconscious force (Boudon, 1979). Insofar as it is based on the assumption of rationality - such as the example of the explanation of collective behaviour borrowed from Coleman - the rational choice model guarantees against any explanation infected by black boxes. It leads to ultimate explanations that do not require any additional questions or whose contents cannot be substantially improved by adding new information produced outside its frame. 
Boudon timely points out that in the rational choice model, "rationality" is defined by the cost-benefit operation or expected utility. It therefore cannot legitimately claim to generality, and is unable to be applied to the most different sociological phenomena. Boudon offers four critical examples. The first one concerns the demand for education mentioned above. The expected utility model is unable to give an account of the interaction effect between students' social background, their level of academic attainment and their demand for further education. In contrast, Boudon's $(1973,2007,2010)$ cognitive theory is able to explain why the influence of students' social class is even higher on demand whereas the academic achievement is lower.

The second one is related to the voting paradox to which Boudon (1997) devotes a full analysis. According to the rational choice model prediction, citizens should not vote to the extent that the costs of voting largely outweigh the benefits. Yet they vote. The third example focuses on what he calls "the overreaction paradox". In many circumstances, the violent individual reaction to insignificant daily life events is disproportionate to the costs. Sometimes costs are immeasurable compared to profit, which is zero or negative.

Finally, the fourth example, which is the most important, is related to the explanation of beliefs. In the last three cases, we are not forced to accept the heavy assumption of actors' irrationality. We should simply question the claim to generality of rationality as supposed by the expected utility model. In addition, cognitive and normative statements as well as beliefs concerning ends and not means are beyond the domain of validity of the rational choice model. This model can account for beliefs formally translated by the statement " $\mathrm{X}$ is good because $\mathrm{X}$ removes unwanted consequences" since in this proposition $\mathrm{X}$ refers to its consequences. But it does not apply to nonsequential normative beliefs that have nothing to do with the consequences of X. When we say "X is good," X does not refer to its possible consequences. Such statements refer to what Weber meant by "axiological" rationality or "Wertrationalität" opposed to "Zweckrationalität" or instrumental rationality that is mean-end rationality.

Boudon's cognitive theory extends the notion of rationality and generalises it in order to integrate instrumental rationality, cognitive rationality and axiological rationality. It is based on four assumptions. For the first one, actions, beliefs and attitudes are perceived by the actor as meaningful, that is to say, based on reasons. The other three specify the conditions under which the three types of rationality are applied. It should be noted that this theory does not apply to all actions and accepts the existence of a-or irrational actions in the meaning Weber $(1913,1922)$ gives to traditional and affectual behaviours (particularly emotional), two of the four types of actions with Zweckrationalität and Wertrationalität actions. But a good research strategy must first begin by identifying the reasons behind the action or belief and not by using the a-or irrationality hypothesis that could lead to an aporia.

By reconstructing the chain of the actor's supposed reasons, social science proposes a theory that generates empirically testable propositions. 
The rational choice model becomes a special case of Boudon's cognitive theory for different reasons. While offering the same epistemological benefits as the first, by for example allowing the construction of hypothetico-deductive and predictive models and explaining mean-end actions, Boudon's theory is more general than the expected utility model that is unable to make intelligible non mean-end phenomena. If cognitive theory gives the impression that it is not as unified as the rational choice model, it is due to the diversity of the types of reasons it takes into account and which depends on the nature of the circumstances in which actions, beliefs and attitudes are taken in or adopted.

\section{Bibliographic references}

Bernard, Claude (1865). Introduction à l'étude de la médecine expérimentale, 3rd edition. Paris: Delagrave, 1912.

- (1947). Principes de médecine expérimentale. Paris: Presses Universitaires de France.

Boudon, Raymond (1964a). "La statistique psychologique de Tarde". Annales internationales de criminologie. In: Boudon (1971).

- (1964b). "Les mécanismes sociaux des abandons de poursuite". Année sociologique, $111-244$.

- (1967). L'analyse mathématique des faits sociaux, Paris, Plon.

- (1970). "Essai sur la mobilité sociale en Utopie". Quality and Quantity, IV, 2, 212-242.

- (1971). "Éléments pour une théorie formelle de la mobilité". Quality and Quantity, V, 2, 39-86.

- (1973). L’inégalité des chances. La mobilité sociale dans les sociétés industrielles. Paris: A. Colin.

- (1979). La logique du social. Paris: Hachette.

- (1984). La place du désordre. Paris: Presses Universitaires de France; tr. Theories of social change, 1986.

- (1986). "L'intellectuel et ses publics". In: Reynaud, J.D. and Grafmeyer, Y. (eds.) Français, qui êtes-vous? Des essais et des chiffres. Paris: La Documentation française.

- (1990). L'art de se persuader. Paris: Fayard. Tr. The Art of Self-Persuasion. The Social Explanation of False Beliefs. Polity, 1997.

— (1997). "Peut-on être positiviste aujourd'hui". In: Cuin, C.-H. (ed. 1997). Durkheim d'un siècle à l'autre. Lectures actuelles des Règles de la méthode sociologique, Paris: Presses Universitaires de France.

- (1998a). "Social mechanisms without black bloxes". In: Hedstrom, P. and SwedBERG, R. (eds.). Social mechanisms. An analytical approach to social theory. Cambridge: Cambridge University Press.

- (1998b). "Les formes élémentaires de la vie religieuse: une théorie toujours vivante". Année Sociologique, vol. 49, 149-198.

- (1999). Le sens des valeurs. Paris: Presses Universitaires de France. The Origin of Values, 2013.

- (2007). Essai sur la théorie de la rationalité. Paris: Presses Universitaires de France.

- (2009). "Why I became a sociologist". In: Cherkaoui, M. and Hamilton, P. (eds.) Raymond Boudon. A Life in Sociology, vol. I, 53-75. Oxford: Bardwell Press..

- (2010). La sociologie comme science. Paris: La Découverte, Eng.tr. Sociology as Science. Oxford: Bardwell Press, 2013. 
- (2011). "La nature de la religion selon Durkheim”. In: Boudon, R. (ed.). Durkheim fut-il durkheimien. Paris: A. Colin.

Bunge, Mario (1967). "Scientific Research". In: The studies of the foundations, methodology, and philosophy of science. Berlin: Springer Verlag.

Cherkaoui, Mohamed (1997). "La théorie de l'explication chez Durkheim". In: Cuin, C.H. (ed.). Durkheim d'un siècle à l'autre. Lectures actuelles des Règles de la méthode sociologique. Paris: Presses Universitaires de France.

- (1998). Naissance d'une science sociale. La sociologie selon Durkheim. Geneva: Droz.

- (2005). Invisible codes. Oxford: Bardwell Press.

- (2007). Good intentions. Oxford: Bardwell Press.

- (2008). Durkheim and the puzzle of social complexity. Oxford: Bardwell Press.

- (2011). Crise de l'Université. Le nouvel esprit académique et la sécularisation de la production intellectuelle. Geneva-Paris: Droz.

Сномsкy, Norman (1964). "Current issues in linguistic theory". In: Fodor, J. A. and Katz, J. J. (eds.). The structure of Language. Readings in the philosophy of language. Prentice Hall: Englewood Cliffs.

Coleman, James S. (1990). Foundations of social theory. Cambridge: The Belknap Press of Harvard University Press.

Comte, Auguste (1830-1842). Cours de philosophie positive. New ed. Paris: Hermann, 1975.

Descartes, René (1644). Principes de la philosophie. New ed. Adam and Tannery, vol. VIII-1. Paris: Vrin, 1964.

Duнem, Pierre (1906). La théorie physique. Son objet, sa structure. New ed. Paris: Vrin 2007

Durkheim, Émile (1895). Les règles de la méthode sociologique. Paris: Alcan. New ed. Paris: Presses Universitaires de France, 1963.

- (1897). Le suicide. Étude de sociologie. Paris: Alcan (2nd ed. 1912).

- (1912) Les formes élémentaires de la vie religieuse, Paris: Alcan. New ed. Paris: Presses Universitaires de France, 1968.

FARARO, Thomas (1969a). "The nature of mathematical sociology". Social Research, XXXVI, 75-92.

- (1969b). "Stochastic processes". In: BorgatTa, Edgar F. (ed). Sociological methodology. San Francisco: Josey Bass.

- (1989). The meaning of General Theoretical Sociology. Tradition and formalization. Cambridge: Cambridge University Press.

Harré, Rom (1970). Principles of Scientific Thinking. Chicago: University of Chicago Press.

Hauser, Robert M. (1974). "Review essay: On Boudon's model of social mobility". American Journal of Sociology, LXXXI, 911-928.

Hempel, Carl (1965). Aspects of scientific explanation and other essays in the philosophy of science. New York: The Free Press.

LeBon, Gustave (1895). Psychologie des foules. New ed. Retz: Paris, CEPL, 1975.

LÉvy-Bruhl, Lucien (1922). La mentalité primitive. Paris: Alcan. New ed. Paris: Presses Universitaires de France, 1960.

Lipset, Seymour M. and ZetTerberg, Hans (1956). "A theory of social mobility”. In: The transactions of the Third World Congress. London: International Sociological Association, 155-177.

Machlup, Fritz (1964). "Professor Samuelson on theory and realism". American Economic Review, 55, 733-36. 
Meyerson, Emile (1921). De l'explication dans les sciences. París: Fayard.

Newton, Isaac (1687). Philosophiae Naturalis Principia Mathematica, tr. Mathematical Principles of Natural Philosophy.

QuÉTELET, Adolphe (1835). Sur l’homme et le développement de ses facultés ou essai de physique sociale. Paris: Bachelier. New ed. Paris: Fayard, 1991.

SAmuelson, Paul (1964). "Theory and realism: A reply", American Economic Review, vol. 54, 736-39.

Schelling, Thomas (1978). Micromotives and macrobehavior. New York: Norton and Co.

Simon, Herbert (1952). "A formal theory of interaction in social groups". American Sociological Review, XVII. In: Simon (1957) Models of man. Social and rational. New York: John Wiley.

- (1955). "Mechanisms involved in pressures toward uniformity in groups". Psychological Review, LXII. In: Simon (1957) Models of man. Social and rational. New York: John Wiley.

— (1968). "On judging the plausibility of theories". In: Simon, Herbert (1977). Models of discovery. Dordrecht: Reidel Publishing Co.

Tarde, Gabriel (1895). Les lois de l'imitation. New ed. Geneva: Slatkine, 1979.

Weber, Max (1913). "Über einige Kategorien der verstehenden Soziologie". In: Weber, Max (1922). Aufsätze zur Wissenschaftslehre. Tübingen: Mohr.

- (1922). Wirtschaft und Gesellschaft. Tübingen: Mohr. 